\title{
Far from Expectation: A Systematic Literature Review of Inclusive Education in Indonesia
}

\author{
Susanna Vonny N. Rante ${ }^{1}$, Helaluddin ${ }^{2,}$, Hengki Wijaya ${ }^{3}$, Harmelia Tulak ${ }^{1}$, Umrati ${ }^{4}$ \\ ${ }^{1}$ Universitas Kristen Indonesia (UKI) Toraja, South Sulawesi, Indonesia \\ ${ }^{2}$ Universitas Islam Negeri (UIN) Sultan Maulana Hasanuddin Banten, Indonesia \\ ${ }^{3}$ Sekolah Tinggi Filsafat Jaffray, Makassar, South Sulawesi, Indonesia \\ ${ }^{4}$ Institut Agama Islam As’adiyah Sengkang, Wajo, South Sulawesi, Indonesia
}

Received August 14, 2020; Revised October 22, 2020; Accepted November 1, 2020

\section{Cite This Paper in the following Citation Styles}

(a): [1] Susanna Vonny N. Rante, Helaluddin, Hengki Wijaya, Harmelia Tulak, Umrati , "Far from Expectation: A Systematic Literature Review of Inclusive Education in Indonesia," Universal Journal of Educational Research, Vol. 8, No. 11B, pp. 6340 - 6350, 2020. DOI: 10.13189/ujer.2020.082273.

(b): Susanna Vonny N. Rante, Helaluddin, Hengki Wijaya, Harmelia Tulak, Umrati (2020). Far from Expectation: A Systematic Literature Review of Inclusive Education in Indonesia. Universal Journal of Educational Research, 8(11B), 6340 - 6350. DOI: 10.13189/ujer.2020.082273.

Copyright $@ 2020$ by authors, all rights reserved. Authors agree that this article remains permanently open access under the terms of the Creative Commons Attribution License 4.0 International License

\begin{abstract}
The purpose of this Systematic Literature Review (SLR) is to identify: (a) research topics, (b) research methods used, and (c) research results on inclusive education in Indonesia. This study was an SLR using the PRISMA model by identifying various appropriate and relevant literature. The PRISMA model adopted in this study contains four stages: identification, screening, eligibility, and inclusion. Data search was carried out using criteria determined by researchers from various search engines such as Google Scholar, ERIC, Scopus, Researchgate, and others, which resulted in 9 articles for further analysis. Furthermore, the data were analyzed using a qualitative approach in describing the research findings. The results showed that three main research themes have been found, namely the implementation of inclusive education, teaching \& learning in inclusive classrooms, and the inclusive education curriculum. Outline, the analysis results of these articles stated that the implementation of inclusive education in Indonesia is still not as expected. These findings are expected to become the basis for teachers, education observers, and education policymakers, both local and central government or the Ministry of Education to implement education policies that support the progress of inclusive education in Indonesia.
\end{abstract}

Keywords Inclusive Education, Inclusive School, Systematic Literature Review (SLR)

\section{Introduction}

One of the issues of education that still remains "interesting" to be discussed until now is the issue of inclusive education. This education movement is not a follow-up to the universal declaration of human rights. Inclusive education is also interpreted as a form of implementation of "education for all" which means that all children in the world must have equal access with their peers to all levels of education [1].

In fact, many children with special needs in all parts of the world can not enjoy education in public schools. UNESCO claims more than $90 \%$ of children with disabilities in developing countries can not access schools and $50 \%$ of those enrolled in schools are capable of reaching secondary school levels [2]. Even though the United Nations issued a policy on the Right of the Child in 1989 to equalize the rights of all children, in reality, children with disabilities still face discrimination and are marginalized too far from their usual friends [3].

Inclusive education is not a global education policy without conflict. This policy presents a dispute about what the meaning of inclusive education really is. In other words, the concept of inclusive education is still a controversial concept because many researchers and 
educators express concern about the effects of inclusion [4]. Until now, the theoretical construction of this type of education is still the subject of interpretation and declination, which tends to vary [5].

From American's and Europeans' perspectives, inclusive education's main feature is to place children with special needs in inclusive schools [6]. Adherents of this perspective assume that the educational process that combines all children into one class, regardless of psychological and physical background, can cause exclusion and abuse of physical and mental disorders [7]. In other words, the education system by combining children with special needs in public schools will only cause new problems.

On the other hand, the definition of inclusive education emphasizes a broader philosophical vision in creating the welcoming of minority groups such as refugees, rural communities, and orphans [8]. In Salamanca World Conference on Special Needs Education, the perspective of inclusive education is interpreted as granting equal access rights for children with special needs in the general education environment [9]. In some countries, this education is also considered as an approach to serving children with disabilities in public schools [10].

In its development, the definition of inclusive education is not only limited to the process of integrating children with special needs into public schools but also extends to other aspects. The increasingly diverse school population in the last three decades proves that the school is now inhabited by students with diverse cultures, socioeconomic backgrounds, languages, family structures, and different bits of intelligence and abilities [11]. Internationally, the inclusive education system is a form of reform that supports and welcomes diversity among students [12]. The fact that children have their own uniqueness, such as diversity of ways of thinking, intelligence and methods of learning must be accommodated by the inclusive school [13]. In addition, inclusive education has been recognized as a critical strategy for ensuring "education for all" in developing countries through policy reform, awareness creation, and development for teachers [14].

Indonesia, as a developing country, has challenges that are not easily related to the implementation of inclusive education. One of them is a policy that must be taken by considering two crucial issues, namely adopting international conventions and how to maintain their uniqueness as developing countries in inclusive education [15].

Other challenges also relate to teacher readiness factors which are considered as the primary determinant of success in implementing inclusive education. In fact, there are many shortcomings of general teacher competence in conveying the learning process in inclusive classroom practice [16]. However, it should be noted that there is no definitive approach to the formation of skills needed by teachers in this case [17].
Even though in recent years there have been positive changes related to inclusive education, there are still many gaps between children with special needs and ways of dealing with their obligations by the school and the community [18]. For this reason, researchers conducted a literature review to review, identify, and synthesize various studies on inclusive education in Indonesia. The data was obtained through a process of analysis of several popular international journal articles that raised the theme of inclusive education in Indonesia with a number of predetermined criteria. Thus, the article's research question is what themes are the research issues on inclusive education in Indonesia during 2014-2019?

\section{Literature Review}

\subsection{Inclusive Education}

The idea of inclusive education emerged after the evolution of human rights in the last few decades. This change wants justice and equality in education for both children and inclusive children. It requires adaptation, differentiation, and modification to the world of education based on the needs and potentials of students who express the aspects of opportunity and justice of human rights [19].

Inclusive education is a process of responding to children's diversity through increasing participation in classrooms and reducing exclusion in the world of education [20]. This means that this education system meets all children's needs, including children with special needs in public schools. The same thing was also stated by Khan et all. [2] which says that inclusive education is an obligation to provide quality education for children in public schools by giving maximum educational services.

In essence, inclusive education requires teachers in public schools to cater to diverse student populations academically, socially, and culturally [21]. In addition to the teacher, the principal is obliged to accept and be committed to this philosophy [22]. Therefore, inclusive education is considered the fairest and most adequate method of educating all children [23].

The implementation of inclusive education still faces many obstacles, especially in developing countries. Proponents of inclusive education claim that there is a need to make radical changes and reform the structure of education. One of the changes referred to is the adjustment of the curriculum, which provides equal learning opportunities for all children [24].

Inclusive education reaps a lot of controversies, which led to their inadvertently trying to implement this type of education [23] [25] [26] [27]. One of the schools of inclusive education believes that inclusive education should only be focused on the adaptation of regular classes to accept and accommodate students with disabilities [28]. But on the other hand, experts state that the broader 
philosophical vision of inclusive education is to create a culture and environment that welcomes minority groups to learn together without distinction and exclusion [29] [30] [31].

\subsection{Systematic Literature Review}

One type of literature review method is the Systematic Literature Review (SLR). This method is a research method that is carried out through rigorous examination of previous studies using explicit criteria in answering research questions [32]. Another definition states that SLR is a research activity by reviewing the literature based on an analytic framework and interpreting the results, which are also known as "defining the body of literature," [33] [34] [35].

The SLR method is characterized by the activity of seeking relevant information to identify, assess, and interpret the results of investigations about problems of concern to researchers [36]. Some of these activities can be categorized as rigorous processes in SLR studies. This rigorous process has several objectives, namely (a) controlling the topic to be investigated to consider the quality of the research, (b) summarizing certain evidence about a theme, (c) identifying research shortcomings and strengths, and (d) suggesting new research with a theoretical framework, in certain research fields [37].

The SLR method has several advantages over unstructured reviews. This method adopts a replicable, scientific, and transparent process [38] [39] [40]. There are many models of the SLR method proposed by experts. One such model is the Preferred Reporting Item for Systematic Reviews and Meta-analysis (PRISMA). This model is used to make a systematic, precise, and reliable literature review [41] [42] [43].

There are many models of the SLR method proposed by experts. One such model is the Preferred Reporting Item for Systematic Reviews and Meta-analysis (PRISMA). This model is used to make a systematic, precise, and reliable literature review [44]. The PRISMA model defines a systematic review as a review of clearly formulated questions using systematic and explicit methods to identify, select, and critically assess relevant research results [45].

\section{Research Methodology}

\subsection{Research Design}

This study used the Systematic Literature Review (SLR) method, which aims to collect, identify, analyze, and synthesize various studies on inclusive education in Indonesia. SLR is a literature review that is firmly attached to a set of scientific methods explicitly with the aim of avoiding systematic or biased errors [46]. This study uses several stages as suggested by Peter [47] about preferred reporting items for systematic reviews and meta-analysis or PRISMA. These stages are identification, screening, eligibility, and inclusion. The following Figure 1 is a glimpse of the systematic process of answering this research question.

Furthermore, based on the results of the data search as illustrated in the chart above, nine articles were further analyzed. The identity of the article is summarized in table 1.

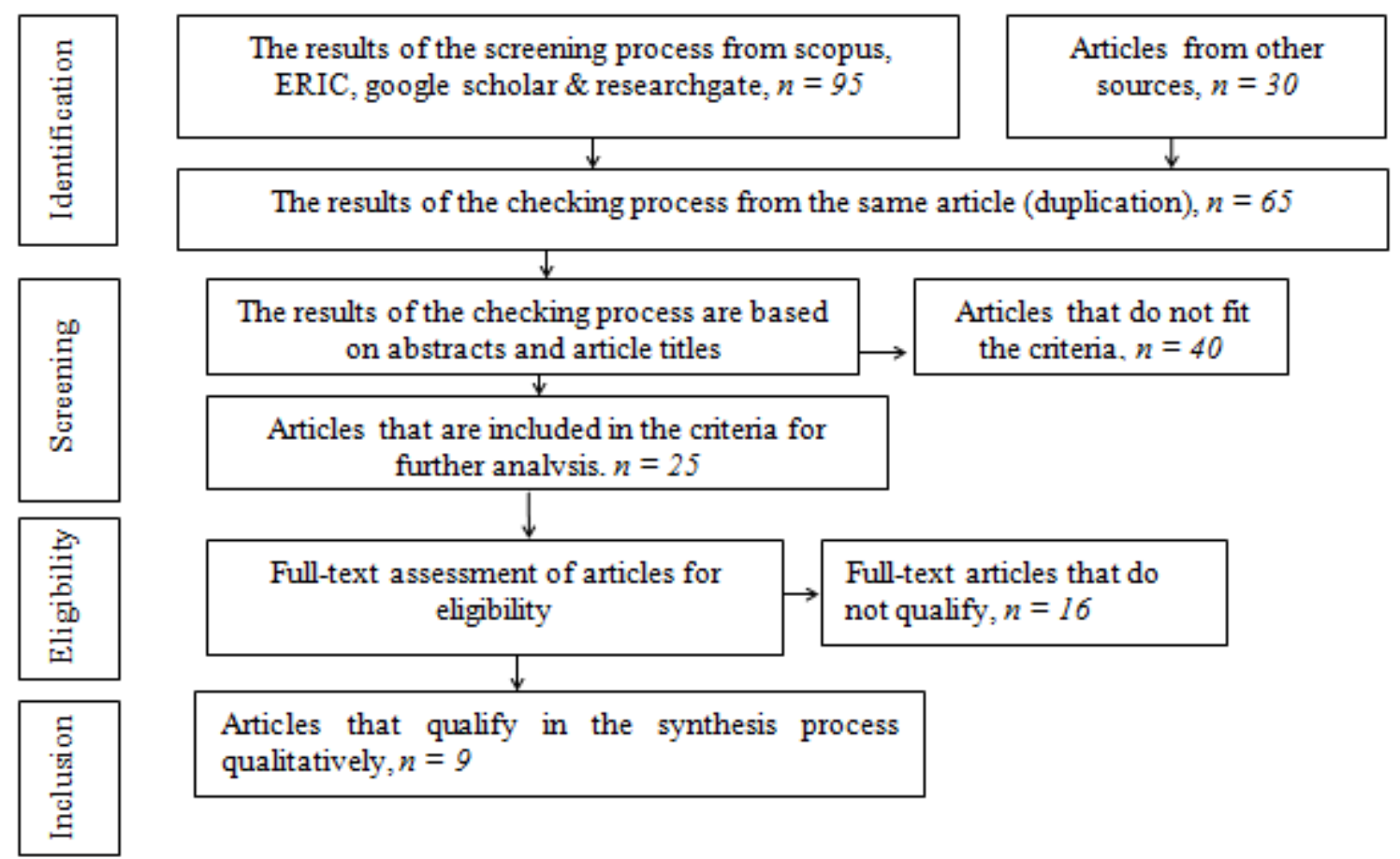

Figure 1. Research Data Search \& Selection Flow 
Table 1. Identiats the articles to be analyzed further

\begin{tabular}{|c|c|c|c|}
\hline No & Article Title & Author Name & Journal Name \\
\hline 1. & $\begin{array}{l}\text { Teaching English to Students with An Autism Spectrum } \\
\text { Disorder in The Regular Classroom in Indonesia }\end{array}$ & $\begin{array}{l}\text { Padmadewi \& Artini } \\
\text { (2017) }\end{array}$ & International Journal of Instruction \\
\hline 2. & $\begin{array}{c}\text { The Impact of Quantum Teaching Strategy on Student Academic } \\
\text { Achievements and Self-esteem in Inclusive School }\end{array}$ & $\begin{array}{l}\text { Gunarhadi, Kassim, \& } \\
\text { Shaari (2014) }\end{array}$ & $\begin{array}{l}\text { Malaysian Journal of Learning } \\
\text { and Instruction }\end{array}$ \\
\hline 3. & $\begin{array}{l}\text { The Readiness of General Elementary Schools to become } \\
\text { Inclusive Elementary Schools: A Preliminary Study in Indonesia }\end{array}$ & $\begin{array}{c}\text { Rasmitadila \& } \\
\text { Tambunan (2018) }\end{array}$ & $\begin{array}{l}\text { International Journal of Special } \\
\text { Education }\end{array}$ \\
\hline 4. & $\begin{array}{c}\text { Elementary School Teachers’ Perception of Public Inclusive } \\
\text { Elementary School readiness Formation }\end{array}$ & $\begin{array}{l}\text { Rasmitadila, Tambunan, } \\
\text { \& Rahmadtullah (2018) }\end{array}$ & $\begin{array}{l}\text { International Journal of Special } \\
\text { Education }\end{array}$ \\
\hline 5. & $\begin{array}{l}\text { Perceptions of Inclusion Education by Parents' Elementary } \\
\text { School-aged Children in Lampung, Indonesia } \\
\end{array}$ & $\begin{array}{l}\text { Adiputra, Mujiati, \& } \\
\text { Hendrowati (2019) }\end{array}$ & International Journal of Instruction \\
\hline 6. & $\begin{array}{l}\text { Curriculum Reform in Indonesia: Moving from An Exclusive to } \\
\text { An Inclusive Curriculum }\end{array}$ & $\begin{array}{l}\text { Mukminin, Habibi, } \\
\text { Prasojo, Idi, \& Hamidah } \\
\text { (2019) }\end{array}$ & $\begin{array}{l}\text { Central for Educational Policy } \\
\text { Studies Journal (CEPS Journal) }\end{array}$ \\
\hline 7. & $\begin{array}{c}\text { How Students with Mathematics Learning Disabilities } \\
\text { Understand Fraction: A Case from the Indonesian Inclusive } \\
\text { School }\end{array}$ & $\begin{array}{l}\text { Ikhwanudin \& Suryadi } \\
\text { (2018) }\end{array}$ & International Journal of Instruction \\
\hline 8. & $\begin{array}{c}\text { Indonesian Teachers’ Epistemological Beliefs and Inclusive } \\
\text { Education }\end{array}$ & $\begin{array}{l}\text { Sheehy, Budiyanto, } \\
\text { Kaye, \& Rofiah (2019) }\end{array}$ & Journal of Intellectual Disabilities \\
\hline 9. & $\begin{array}{l}\text { The Pedagogic Beliefs of Indonesian Teachers in Inclusive } \\
\text { Schools }\end{array}$ & $\begin{array}{l}\text { Sheehy \& Budianto } \\
\text { (2015) }\end{array}$ & $\begin{array}{l}\text { International Journal of Disability, } \\
\text { Development, and Education }\end{array}$ \\
\hline
\end{tabular}

\subsection{Data Collection}

Search for data sources in this research was accessed through various electronic databases such as Google Scholar, Scopus, Researchgate, ERIC, and others. There are several keywords used in data search, namely inclusive education, inclusive school, inclusive class, and inclusion education. In addition, the researchers also used several criteria in analyzing data. The analysis criteria in this study were developed by the researcher by referring to the requirements previously carried out by Hoang [48], Kwon \& Lee [46], Kartal \& Guner [49], \& Williams [50]. The selection of these criteria is based on the SLR model equation, namely Preferred Reporting Items for Systematic Reviews and Meta-analysis (PRISMA). The articles chosen are articles published by reputable scientific journals because journal media are considered better because they use a peer-review system.

Table 2. Inclusion \& Exclusion Criteria

\begin{tabular}{ccc}
\hline No & Inclusion Criteria & Exclusion Criteria \\
\hline 1. & $\begin{array}{c}\text { Journal articles are written by } \\
\text { Indonesian or foreign writers }\end{array}$ & $\begin{array}{c}\text { National or international } \\
\text { seminar proceedings }\end{array}$ \\
\hline 2. & Research location in Indonesia & $\begin{array}{c}\text { Research locations } \\
\text { outside Indonesia }\end{array}$ \\
\hline Published in reputed & $\begin{array}{c}\text { international journals (indexed } \\
\text { by Scopus as recommended by } \\
\text { the Ministry of Education and } \\
\text { Culture of the Republic of } \\
\text { Indonesia) }\end{array}$ & $\begin{array}{c}\text { Articles published in } \\
\text { local or international } \\
\text { journals are not } \\
\text { reputable }\end{array}$ \\
\hline 4. & Articles in English & Articles in Indonesian \\
\hline 5. & Year of publication between & 2014-2019
\end{tabular}

\subsection{Data Analysis}

In connection with the research question, the data analysis used in this study is content analysis. This technique is used to determine trends at the descriptive level of studies conducted on a particular subject [51]. There are three steps taken in analyzing data with this technique, namely: (a) coding, (b) grouping codes based on similarities, and (c) data abstraction [52]. Furthermore, the results of the analysis were validated using member checking techniques and peer review. The member checking was carried out by the researchers in the group as many as 4 people [53] while the peer review process involved two experts in the field of education (1 expert from an educational psychology background and one expert from an inclusive education expert) in examining and providing advice [54].

\subsection{Validity \& Reliability}

The SLR method used in this study, both at the data collection and analysis stage, is stated as one indicator of validity. It is confirmed by the existence of a comprehensive explanation at each step of the research. In 2 articles that were randomly selected and encoded among five researchers, the consistency value was $90 \%$. This consistency value is calculated based on the formula proposed by Miles and Huberman [55]. From the results of the consistency, it can be stated that the results of the study have been valid and reliable. 


\section{Results}

\subsection{Research Methods Used}

The following table provides an overview of the research methods used in the articles reviewed. There are three research methods used, namely qualitative, quantitative, and mix-methods methods. Besides, there was also an article which is an article with a theoretical study approach or literature review. Four items use qualitative methods, 3 subjects with quantitative methods, 1 article using mix-methods, and 1 article with a theory study approach.

There were four articles in this literature review that use qualitative methods in generating or collecting research data. All four items explore inclusive education in schools. The first article seeks to explore information on three students who have learning disabilities in mathematics on fractions sub discussion [56]. Furthermore, another article that uses students as research subjects is a study of 20 students who have autistic spectrum disorder (ASD) using observation and interview methods [57]. Besides students, there are several other research subjects used in some of these studies. The research subjects in question include teachers, parents, school administrators, and school committees [58] [59].

Quantitative methods are also used in 3 articles in this review. One of them is a study conducted by Gunarhadi [60] who use research instruments in the form of tests and questionnaires. This study proves that the quantum teaching strategy has a positive impact on learning outcomes in Indonesian and natural science subjects. Another quantitative research is a study conducted by Rasmitadilla et al. [61] and Sheehy et al. [62]. Both of these studies chose teachers as research subjects using instruments in the form of questionnaires.

Another method used in one of the research articles reviewed was mix-methods. This study uses a combination of questionnaires and interviews in gathering data. The questionnaire instrument was aimed at 140 teachers and an interview instrument with 20 teachers) [63]. Furthermore, one research article in this review is a theory study article without listing the research methods used [64].

Table 3. Research Designs

\begin{tabular}{|c|c|c|c|}
\hline $\begin{array}{l}\text { Research } \\
\text { Approach }\end{array}$ & Data collection \& Instruments & Research Participants & Author(s) \\
\hline \multirow{4}{*}{$\begin{array}{l}\text { Qualitative } \\
\quad(n=4)\end{array}$} & $\begin{array}{l}\text { Tests, observation, analysis of } \\
\text { media \& documents, and } \\
\text { interviews with teachers }\end{array}$ & $\begin{array}{l}\text { Three students who have learning disabilities } \\
\text { in Mathemstics }\end{array}$ & $\begin{array}{c}\text { (Ikhwanuddin \& Suryadi, } \\
\text { 2018) }\end{array}$ \\
\hline & Observation and interviews & $\begin{array}{c}20 \text { students who have Autistic Spectrum } \\
\text { Disorder (ASD) }\end{array}$ & (Padmadewi \& Artini, 2017) \\
\hline & Face-to-face interview & $\begin{array}{c}50 \text { school administrators, } 50 \text { elementary school } \\
\text { teachers, } 50 \text { student parents, and } 30 \text { school } \\
\text { committees }\end{array}$ & $\begin{array}{l}\text { (Rasmitadila \& Tambunan, } \\
\text { 2018) }\end{array}$ \\
\hline & Interview & 117 parents of students & Adiputra \& Mujiyati, 2019) \\
\hline \multirow[t]{3}{*}{$\begin{array}{l}\text { Quantitative } \\
(\mathrm{n}=3)\end{array}$} & Test and questionnaire & 78 elementary students from 5 districts & $\begin{array}{l}\text { Gunarhadi, Kassim, \& Shaari, } \\
\text { 2014) }\end{array}$ \\
\hline & Open-questionnare & 115 public elementary school teachers & (Rasmitadila et al., 2018) \\
\hline & Questionnaire & $\begin{array}{c}267 \text { teachers at the national seminar in } \\
\text { Surabaya (36\% public school teachers, 32\% } \\
\text { special school teachers, and 32\% inclusive } \\
\text { school teachers) }\end{array}$ & $\begin{array}{l}\text { (Sheehy \& Budiyanto et al., } \\
\text { 2019) }\end{array}$ \\
\hline $\begin{array}{l}\text { Mix-methods } \\
\quad(\mathrm{n}=1)\end{array}$ & $\begin{array}{c}\text { Questionnaire \& } \\
\text { semi-structured interviews }\end{array}$ & $\begin{array}{l}140 \text { teachers using questionnaires \& } 20 \\
\text { teachers using interviews }\end{array}$ & (Sheehy \& Budiyanto, 2015) \\
\hline $\begin{array}{l}\text { Theoretical } \\
\text { review }(n=1)\end{array}$ & - & - & $\begin{array}{c}\text { Mukminin, Habibi, Prasojo, Idi, } \\
\text { \& Hamidah (2019) }\end{array}$ \\
\hline
\end{tabular}




\subsection{Theme \& Results of The Article Under Review}

This section is presented to provide a general description of some of the themes raised in the articles reviewed. Broadly speaking, there are three main themes in this review. The three topics were learning in inclusive classes, the implementation of inclusive education, and an overview of inclusive education.

Table 4. The Research Theme of The Article being Reviewed

\begin{tabular}{|c|c|c|c|}
\hline Theme & $\begin{array}{c}\text { Research } \\
\text { Sub-theme }\end{array}$ & Remarkable Outcomes of Research & Author(s) \\
\hline \multirow[t]{3}{*}{$\begin{array}{l}\text { Teaching \& } \\
\text { learning }\end{array}$} & $\begin{array}{l}\text { Teaching } \\
\text { english to } \\
\text { students with } \\
\text { ASD }\end{array}$ & $\begin{array}{l}\text { The Individual education plan (IEP) which is equipped with } \\
\text { visual media through a "buddy program” is very suitable in } \\
\text { helping students learn English. This strategy is very effective in } \\
\text { implementing inclusive class programs }\end{array}$ & Padmadewi \& Artini (2017) \\
\hline & $\begin{array}{l}\text { Quantum } \\
\text { teaching } \\
\text { strategy in the } \\
\text { learning of } \\
\text { bahasa }\end{array}$ & $\begin{array}{l}\text { T-test results show that the quantum teaching strategy has more } \\
\text { impact on the learning achievement of Indonesian and science } \\
\text { subjects compared to using conventional approaches }\end{array}$ & $\begin{array}{c}\text { Gunarhadi, Kassim, \& Shaari } \\
\text { (2014) }\end{array}$ \\
\hline & $\begin{array}{l}\text { Mathematics } \\
\text { learning }\end{array}$ & $\begin{array}{c}\text { Students know the standard denominator method in adding } \\
\text { fractions but are wrong in applying it. } \\
\text { Students use the common denominator approach in multiplying } \\
\text { fractions. } \\
\text { In fraction division, students mistakenly apply the multiplay } \\
\text { invert algorithm. }\end{array}$ & $\begin{array}{l}\text { Ikhwanudin \& Suryadi } \\
\text { (2018) }\end{array}$ \\
\hline \multirow[t]{5}{*}{$\begin{array}{l}\text { Implementa-tio } \\
\mathrm{n} \text { of inclusive } \\
\text { education }\end{array}$} & $\begin{array}{l}\text { Perceptions } \\
\text { study }\end{array}$ & $\begin{array}{l}\text { Results: } 60 \% \text { of school principals are ready to implement } \\
\text { inclusive schools, } 92 \% \text { of schools do not have supporting } \\
\text { facilities, } 94 \% \text { of schools do not have extraordinary teachers, } \\
72 \% \text { of schools have not received information about inclusive } \\
\text { schools, } 80 \% \text { of schools have not collaborated with institutions } \\
\text { that are relevant to education inclusive, and } 82 \% \text { of schools do } \\
\text { not yet have an inclusive school administration system. } \\
\text { Conclusion: primary schools are not ready to become inclusive } \\
\text { elementary schools (IES). }\end{array}$ & $\begin{array}{l}\text { Rasmitadila, \& Tambunan } \\
\text { (2018) }\end{array}$ \\
\hline & & $\begin{array}{c}\text { Levels of general primary school readiness to become inclusive } \\
\text { schools: } 20 \% \text { are ready, } 49.6 \% \text { are not prepared, and } 30.4 \% \text { are } \\
\text { not prepared. } \\
\text { Factors that become obstacles include: availability of } \\
\text { infrastructure and facilities as much as } 24.35 \% \text {, teacher skills as } \\
\text { much as } 23.48 \% \text {, the presence of special teachers } 20 \% \text {, the } \\
\text { mindset of parents and community as much as } 14.78 \% \text {, problems } \\
\text { of funds as much as } 9.5 \% \text { and } 7.82 \% \text { about government } \\
\text { involvement }\end{array}$ & $\begin{array}{l}\text { Rasmitadila,Tambunan \& } \\
\text { Rachmadtullah (2018) }\end{array}$ \\
\hline & & $\begin{array}{c}\text { Parents with low educational \& socioeconomic status (ESES) are } \\
30 \text { parents with } 25 \text { agreeing and four rejecting. } \\
\text { Parents with moderate ESES were } 41 \text { people with ten parents } \\
\text { agreed and seven people refused } \\
\text { Parents with high ESES as many as } 38 \text { people with } 18 \text { people } \\
\text { who accept and four people reject } \\
\text { Thus, in general, the ESES level does not affect parents’ } \\
\text { perceptions about inclusive education in primary schools }\end{array}$ & $\begin{array}{l}\text { Adiputra, Mujiyati, \& } \\
\text { Hendrowati (2019) }\end{array}$ \\
\hline & $\begin{array}{c}\text { Teachers' } \\
\text { epistemological } \\
\text { beliefs }\end{array}$ & $\begin{array}{l}\text { Teachers in inclusive schools express their ideas about social } \\
\text { constructivists who are stronger than other school teachers. }\end{array}$ & $\begin{array}{c}\text { Sheehy, Budiyanto, Helen \& } \\
\text { Rofiah (2019) }\end{array}$ \\
\hline & $\begin{array}{l}\text { The } \\
\text { pedagogical } \\
\text { beliefs }\end{array}$ & $\begin{array}{l}\text { The results of the study, in general, show that the implicit } \\
\text { orientation of teachers in inclusive education is a social } \\
\text { constructivist. This is reflected in the teacher's report. } \\
\text { In addition, teachers as a unique pedagogy usually need } \\
\text { additional time in organizing good teaching for all. }\end{array}$ & Sheehy \& Budiyanto (2015) \\
\hline $\begin{array}{l}\text { Curriculum of } \\
\text { inclusive } \\
\text { eduation }\end{array}$ & $\begin{array}{l}\text { Inclusive } \\
\text { education in } \\
\text { K13 curriculum } \\
\text { in Indonesia }\end{array}$ & $\begin{array}{l}\text { Indonesia's curriculum that is centered and equated causes } \\
\text { underdeveloped schools in quite difficult situations. } \\
\text { The ASPIRE model is suggested as a type of principal leadership } \\
\text { that can support curriculum reform by integrating inclusive and } \\
\text { exclusive education curricula. }\end{array}$ & $\begin{array}{l}\text { Mukminin, Habibi, Prasojo, } \\
\text { Idi, \& Hamidah (2019) }\end{array}$ \\
\hline
\end{tabular}


The main issue about inclusive education in the study reviewed is related to learning in inclusive classes. There was 33\% (3 studies) that discuss the theme of inclusive learning, namely English learning, Indonesian language learning \& natural science, and mathematics learning. English learning for students with autistic spectrum disorder (ASD) is rated positively by using the Individual Education Plan (IEP) which is equipped with visual media based on "buddy program" [57]. The next study is Indonesian language learning and natural science using quantum teaching methods. This study tries to prove that the quantum teaching method has a good impact on students' learning achievement in both lessons [60] while the third study explores the ability of students in the common denominator for fractional material in mathematics [56].

The second theme that is widely used in the articles reviewed was the implementation of inclusive education in Indonesia. On this theme, the majority of research uses perception studies for teachers, students, parents, and even the school committee. At the elementary school level, the implementation of inclusive education is declared not yet ready to be applied in public primary schools due to facilities, human resources, funds, etc. [59]. Still related to perceptual studies, another sub-theme raised in the research reviewed is the educational \& socioeconomic status associated with perceptions about inclusive education [58], social constructivist beliefs for teachers in inclusive and public schools [62], and the implicit orientation of teachers in inclusive schools [63].

Finally, the theme of the article that needs attention is the curriculum of inclusive education implemented in Indonesia. So far, the curriculum used in Indonesia (2013 syllabus) is still centralized and general in nature [64]. This condition is undoubtedly severe for schools that do not yet have complete facilities or schools that lag behind in quality. For this reason, the principal's leadership model with the ASPIRE Model needs to be implemented. ASPIRE model is a leadership method that refers to Assessment, Synthesis, Planning, Implementation, Review, and Evaluation.

\section{Discussion}

Based on the nine articles' analysis, several main research themes on inclusive education can be grouped. The three main research themes in question are (a) implementation of inclusive education, (b) teaching \& learning in inclusive classrooms, and (c) inclusive education curricula. Regarding inclusive education implementation, two research articles are analyzed, indicating that inclusive education is not yet ready to be applied at the general primary school level with various problems. Other studies have also stated that the most significant obstacles, in this case, are inadequate teacher training and teachers' mindset towards inclusive education [65] [66]. Gronlund, Lim, \& Larsson [67] emphasize that many developing countries experience most of these problems in all parts of the world.

One of the interesting aspects of these various obstacles is the community's perception factor and even teachers about inclusive education itself. In other words, inclusive education's unsuccessfulness is also caused by the teacher's factor in teaching children with special needs. The teaching experience of teachers for decades is considered to have influenced teachers' attitudes towards this philosophy of inclusion, and many teachers even expressed their reluctance to accept this philosophy [68] [69]. For this reason, it is necessary to acquire competencies, instill diversity, and uphold sustainable human rights for the success of inclusive education [70] [71] [69]. Salim et all. [72] explicitly stated that the success of inclusive education is shown by teachers' instructional skills in the classroom and the awareness of all people to accept students with disabilities.

In addition to teachers' perceptions of the philosophy and application of inclusive education in Indonesia, several studies also involved participants from different backgrounds, such as school principals, school committees, school administrators, parents, community, and others. The involvement of various elements of society is also carried out by foreign researchers. Baguisa \& Ang-Manaig [73] stated that inclusive education needs to be supported and collaborated with parents, counselors, teachers, nurses, doctors, and local/central government in developing action plans to assist teachers in dealing with children with special needs. There are very few professionals who have supported teachers and students in the inclusive learning process so far, especially in Croatia [11].

The second theme in the research results is about teaching and learning in inclusive classrooms. Various models, approaches, and methods are used by teachers to teach students with special needs to achieve the expected learning objectives. The use of the Individual Education Plan (IEP) with audio-visual media and quantum models are some of the models used by teachers. Experts consider the quantum model as a learning model that is more fun, effective, and consistent [74]. The advantage of this model is that it is a model that combines all the neural structures of the brain to create meaningful information [75] and can solve problems creatively [76].

Furthermore, the inclusive education curriculum is a theme raised in the articles reviewed. One of them is a study conducted by Mukminin et al. [64]. They stated that the implementation of the 2013 Curriculum (C13) in Indonesia needs development efforts to be able to place better inclusive education. They offer the ASPIRE (Assessment, Synthesis, Planning, Implementation, Review, and Evaluation) model in the current curriculum system. A study that suggests the need for activities to 
promote inclusive education in the school system and increase adequate resources in teaching children with special needs is not much different [5]. Other experts state that institutions should provide appropriate curricula for inclusive education such as (a) content pedagogical curriculum, moral training-based curriculum, (c) independent and creative training for both children with physical and intellectual disabilities, or children with multiple disabilities [77].

From some of the analyzed studies, it can be concluded that inclusive education in Indonesia is still far from what was expected. Likewise, several countries around the world are also facing various challenges that are not light. The existence of disagreements about the meaning \& concept of inclusive education in educational needs is suspected to be a factor in the unsuccessfulness of this inclusive education. This disagreement occurs due to several factors, namely: (a) differences in educational policies, (b) different procedures, (c) identification of different needs of children, and (d) different socio-cultural influences on the interpretation of the inclusive concept [78]. It is also not surprising that Anastasiou \& Kauffman [79] assess that the inclusive education model does not have the desired outcomes for children with diverse educational needs. For this reason, researchers suggest that future research be more focused on expert studies and government policies on inclusive education that is ideal for implementation in Indonesia with its unique socio-cultural background.

\section{Conclusions}

This study is an SLR on inclusive education in Indonesia, which analyzes nine articles that have been published from 2014-2019 in reputable international journals and selected based on predetermined criteria. This article provides a clear picture of SLR inclusive education's current trends by identifying, classifying, and synthesizing research results based on research themes. There are three main themes found based on data analysis: inclusive education, teaching \& learning in inclusive classrooms, and the inclusive education curriculum. In general, Indonesia is considered not ready to implement inclusive education to its full potential, especially in primary schools. The unpreparedness referred to here relates to various factors that influence it, including the socialization of inclusive education programs that have not been maximized, the availability of specialized teachers in public schools or human resources, the availability of facilities and infrastructure (facilities for disabilities), funds, etc.

One limitation of this review is the relatively small number of articles reviewed /analysis. This is caused by the restrictions set as criteria in capturing various items called exclusion \& inclusion criteria. A literature review must be carried out with a broader scope, both in terms of quantity, in producing more comprehensive literature review articles.

\section{REFERENCES}

[1] A. Salim and D. Atnantomi, “Analysis of Teachers' Understanding Level, Needs, and Difficulties in Identifying Children with Special Needs in Inclusive School in Surakarta,” Journal of Education and Learning, vol. 11, no. 4, pp. 352-357, 2017.

[2] I. K. Khan, S. H. Hashmi, and N. Khanum, "Inclusive Education in Government Primary Schools: Teacher Perceptions," Journal of Education and Educational Development, vol. 4, no. 1, pp. 32-47, 2017.

[3] M. Kavkler, M. K. Babuder, and L. Magajna, "Inclusive Education for Children with Specific Learning Difficulties: Analysis of Opportunities and Barriers in Inclusive Education in Slovenia," Center for Educational Policy Studies Journal., vol. 5, no. 1, pp. 31-52, 2015.

[4] M. A. Pappas, C. Papoutsi, and A. S. Drigas, "Policies, Practices, and Attitudes toward Inclusive Education: The Case of Greece,” Social Sciences, vol. 7, no. 90, pp. 1-15, 2018.

[5] D. C. Di Gennaro, E. M. Pace, I. Zollo, and P. Aiello, "Teacher Capacity Building through Critical Reflective Practice for the Promotion of Inclusive Education," Problem of Education in the $21^{\text {st }}$ Century, vol. 60, pp. 5466, 2014.

[6] L. Terzi, "Reframing Inclusive Education: Educational Equality as Capability Equality," Cambridge Journal of Education, vol. 44, no. 4, pp. 479-493, 2014.

[7] R. R. Djone and A. Suryani, "Child Workers and Inclusive Education in Indonesia," The International Education Journal: Comparative Perspectives, vol. 18, no. 1, pp. 4865, 2019.

[8] M. P. Opoku, J. Agbenyega, J-F, W. K. Mprah, J. Mckenzie, and E. Badu, "Decade of Inclusive Education in Ghana: Perspectives of Educators," Journal of Social Inclusion, vol. 8, no. 1, pp. 4-20, 2017.

[9] A. Nishio, S. Tomokawa, J. Kobayashi, T. Mizoue, R. Horita, and M. Yamamoto, "Inclusive Education in Association of Southeast Asian Nations (ASEAN): Literature Review from 1995 - 2015,” School Health, vol. 13, pp. 20-29, 2017.

[10] M. E. L. Ainscow, "Developing Inclusive Education Systems: What are The Levers for Change?,” Journal of Educational Change, vol. 6, pp. 109-124, 2005.

[11] D. Bouillet, "Some Aspects of Collaboration in Inclusive Education-Teachers' Experiences," Center for Educational Policy Studies Journal, vol. 3, no. 2, pp. 93-117, 2013.

[12] D. Mitchell, "Inclusive Education is a Multi-Faceted Concept," Center for Educational Policy Studies Journal, vol. 5, pp. 9-30, 2015.

[13] I. El Khuluqo, "Developing Indonesian Inclusive Educational Model,” International Journal for Studies on 
Children, Women, Elderly and Disabled, vol. 2, no. June, pp. 118-124, 2017.

[14] S. Malak, "Inclusive Education Reform in Bangladesh: Pre-Service Teachers' Responses to Include Students with Special Educational Needs in Regular Classrooms," International Journal of Instruction, vol. 6, no. 1, pp. 195214, 2013.

[15] C. Forlin, "Changing Paradigms and Future Directions for Implementing Inclusive Education in Developing Countries," Asian Journal of Inclusive Education, vol. 1, no. 2, pp. 19-31, 2013.

[16] J. Buli-Holmberg and S. Jeyaprathaban, "Effective Practice Inclusive and Special Needs Education," International Journal of Special Education, vol. 31, no. 1, pp. 119-134, 2016.

[17] Z. A. Movkebayeva, I. A. Oralkanova, M. Bagdat, A. B. Beisenova, and O. G. Belenko, "Model of Formation for Readiness to Work within Inclusive Education in Teachers," International Journal of Environmental \& Science Education, vol. 11, no. 11, pp. 4680-4689, 2016.

[18] UNICEF, "Promoting the Rights of Children with Dissabilities,” Florence, 2007.

[19] T. Vrasmas, "Curriculum for Children with Disabilities in Inclusive Education. A Literature Review," Procedia-Social Behavioral Sciences, vol. 127, pp. 336341, 2014.

[20] UNESCO, Global Monitoring Report 2008: Education for All by 2015. Will We Make it. Paris: United Nations Education, Science and Cultural Organization, 2007.

[21] R. Rose, “Understanding Inclusion, Interpretations, Perspective and Cultures," in Confronting Obstacles to Inclusion: International Responses Developiong Inclusive Schools, Abingdon: Routledge, 2010, pp. 1-6.

[22] G. Kibria, "Inclusive Education and The Developing Countries: The Case of Bangladesh," The Journal of the International Association of Special Education, vol. 6, no. 1, pp. 43-47, 2005.

[23] M. Ainscow, T. Booth, and A. Dyson, "Inclusion and The Standards Agenda: Negotiating Policy Pressures in England,” International Journal of Inclusive Education, vol. 10, no. 4-5, pp. 295-301, 2006.

[24] B. Persson, "Pathways to Inclusion: A Guide to Staff Development," European Educational Research Journal, vol. 5, pp. 152-158, 2006.

[25] P. Clough and J. Corbett, Theories of Inclusive Education: A Student's Guide. London: Sage, 2000.

[26] J. M. Kauffman, “Commentary: Today’s Special Education and Its Messages for Tomorrow," The Journal of Special Education, vol. 132, no. 4, pp. 244-254, 1999.

[27] C. Forlin, Responding to The Need for Inclusive Teacher Education. Future Directions for Inclusive Teacher Education: An International Perspective. London: Routledge, 2012.

[28] U. Sharma, C. Forlin, M. Marella, and F. Jitoko, "Using Indicators As a Catalyst for Inclusive Education in The Solomon Island,” Australian Journal of Teacher Education, vol. 40, no. 5, pp. 103-116, 2017.

[29] M. Ainscow, T. Booth, and A. Dyson, Improving schools, Developing Inclusion. London: Routledge, 2006.

[30] A. Ashman, Education for Inclusion and Diversity. Melbourne: Pearson Education, 2015.

[31] UNICEF, The Right of Students with Dissabilities to Education: A Right-based Approach to Inclusive Education in The CEE/CIS Region. Geneva: UNICEF Regional Office for Central and Eastern Europe and Commonwealth of Independent States, 2011.

[32] H. Helaluddin and A. Alamsyah, "Kajian Konseptual tentang Social-emotional Learning (SEL) dalam Pembelajaran Bahasa,” Al-Ishlah: Jurnal Pendidikan, vol. 11, no. 1, pp. 1-16, 2019.

[33] C. Amundsen and M. Wilson, “Are We Asking The Right Questions? A Conceptual Review of Educational Development Literature in Higher Education," Review of Educational Research, vol. 82, no. 1, pp. 90-126, 2012.

[34] K. E. Matthews et al., "SoTL and Students' Experiences of Their Degree-level Programs: An Empirical Investigation," Teaching and Learning Inquiry, vol. 1, no. 2, pp. 75-89, 2013.

[35] M. M. Kennedy, “Defining A Literature,” Educational Researcher, vol. 36, no. 3, pp. 139-147, 2007.

[36] B. Kitchenham, Procedures for Performing Systematic Reviews. Keele, UK: Keele University, 2004.

[37] B. Kitchenham, D. Budgen, and D. Pearl-Breeton, “Using Mapping Studies as the Basis for Further Research-A Participant-observer Case Study," Information and Software Technology, vol. 53, no. 6, pp. 638-651, 2011.

[38] D. Denyer, D. Tranfield, and J. . Van Aken, "Developing Design Propositions through Research Synthesis," Organization Studies, vol. 29, pp. 393-413, 2008.

[39] A. Macpherson and O. Jones, "Editorial: Strategies for The Development of International Journal of Mangement Reviews," International Journal of Management Reviews, vol. 12, pp. 107-113, 2010.

[40] D. Transfield, D. Denyer, and P. Smart, "Towards a Methodology for Developing Evidence-based-informed Management Knowledge bty Means of Systematics Review,” British Journal of Management, vol. 14, no. 3, pp. 207-222, 2003.

[41] C. L. Wang and H. Clugh, "Intrepreneurial Learning: Past Research and Future Challenges," International Journal of Management Reviews, vol. 16, pp. 24-61, 2014.

[42] S. Kunisch, M. Menz, and B. Ambos, "Changes at Corporate Headquarters: Review, Integration and Future Research,” Journal of Operations Management Reviews, vol. 17, pp. 422-433, 2015.

[43] P. Danese, V. Manf, and P. Romano, "A Systematic Literature Review on Recent Lean Research: State-of-the-art and Future Directions," International Journal of Management Reviews, vol. 20, pp. 579-605, 2018.

[44] D. Moher, A. Liberati, J. Tetzlaff, and D. G. Altman, 
"Preferred Reporting Items for Systematic Reviews and Meta-analysis: The PRISMA Statement," Annals of Internal Medicine, vol. 151, no. 4, pp. 264-269, 2009.

[45] S. B. Hartmann, L. Q. N. Braae, S. Pedersen, and M. S. Khalid, "The Potentials of Using Cloud Computing in Schools: A Systematic Literature Review," TOJET: The Turkish Online Journal of Educational Technology, vol. 16, no. 1, pp. 190-202, 2017.

[46] H. Kwon and E. Lee, "Research Trends and Issues of Educatioan for Sustainable Development-related Research in South Korea,” Journal of Baltic Science Education, vol. 18, no. 3, pp. 379-388, 2019.

[47] M. Peter, T. Diekötter, and K. Kremer, "Participant Outcomes of Biodiversity Citizen Science Projects: A Systematic Literature Review,” Sustainability, vol. 11, no. 2780, pp. 1-18, 2019.

[48] T. Hoang, "Teacher Self-efficacy Research in English as Foreign Language Contexts: A Systematic Review," Journal of Asia TEFL, vol. 15, no. 4, pp. 976-990, 2018.

[49] H. Kartal and F. Guner, "A Review of Articles that Include the Schools' Readiness Dimension," European Journal of Educational Research, vol. 7, no. 3, pp. 431-443, 2018.

[50] P. J. Williams, "Research in Technology Education: Looking Back to Move Forward," International Journal of Technology and Design Education, vol. 23, no. 1, pp. 1-9, 2013.

[51] M. Calik, S. Unal, B. Costu, and F. O. Karatas, "Trends in Turkish Science Education,” Essays in Education, vol. special edition, pp. 23-45, 2008.

[52] S. Elo and H. Kyngas, "The Qualitative Content Analysis Process,” Journal of Advanced Nursing, vol. 62, no. 1, pp. 107-115, 2008.

[53] J. A. Carlson, “Avoiding Traps in Member Checking,” The Qualitative Report, vol. 15, no. 5, 2010.

[54] A. Ragone, K. Mirylenka, F. Casati, and M. Marchese, “A Quantitative Analysis of Peer Review," in 13th International Society of Scientometrics and Informetrics Conference, 2011.

[55] M. B. Miles and A. M. Huberman, An Expanded Sourcebook-qualitative Data Analysis. London: Sage Publications, 1994.

[56] T. Ikhwanudin and D. Suryadi, "How Students with Mathematics Learning Disabilities Understands Fraction: A Case from The Indonesian Inclusive School,” International Journal of Instruction, vol. 11, no. 3, pp. 309-326, 2018.

[57] N. N. Padmadewi and L. P. Artini, "Teaching English to a Student with Autism Spectrum Disorder in Regular Classroom in Indonesia," International Journal of Instruction, vol. 10, no. 3, pp. 159-176, 2017.

[58] S. Adiputra, Mujiyati, and T. Y. Hendrowati, "Perceptions of Inclusion Education by Parents of Elementary School-aged Children in Lampung, Indonesia,” International Journal of Instruction, vol. 12, no. 1, pp. 199-212, 2019.

[59] Rasmitadila and A. R. S. Tambunan, "Readiness of General Elementary Schools to Become Inclusive Elementary Schools: A Preliminary Study in Indonesia,” International
Journal of Special Education, vol. 33, no. 2, pp. 366-381, 2018.

[60] Gunarhadi, M. Kassim, and A. S. Shaari, "The Impact of Quantum Teaching Strategy on Student Academic Achievements and Self-Esteem in Inclusive Schools," Malaysian Journal of Learning Instrustion, vol. 11, pp. 191-205, 2014.

[61] Rasmitadila, A. R. S. Tambunan, and R. Rachmadtullah, "Elementary School Teachers' Perceptions of Public Inclusive Elementary School Readiness Formation," International Journal of Special Education, vol. 33, no. 3, pp. 732-744, 2018.

[62] K. Sheehy, Budiyanto, H. Kaye, and R. Khofidotur, "Indonesian Teachers' Epistemological Beliefs and Inclusive Education," International Journal of Dissability, Development and Education, vol. 23, no. 1, pp. 39-56, 2019.

[63] K. Sheehy and Budiyanto, "The Pedagogic Beliefs of Indonesian Teachers in Inclusive Education,” International Journal of Dissability, Development and Education, vol. 62, no. 5, pp. 469-185, 2015.

[64] A. Mukminin, A. Habibi, L. D. Prasojo, A. Idi, and A. Hamidah, "Curriculum Reform in Indonesia: Moving from an Exclusive to Inclusive Curriculum," Center for Educational Policy Studies Journal, vol. 9, no. 2, pp. 53-72, 2019.

[65] J. Charema, "Inclusive Education in Developing Countries in The Sub Saharan Africa: From Theory to Practice," International Journal of Special Education, vol. 25, no. 1, pp. 87-93, 2010.

[66] S. F. Watson, "Barriers to Inclusive Education in Ireland: The Case for Pupils with A Diagnosis of Intellectual and/or Pervasive," British Journal of Learning Disabilities, vol. 37, no. 4, pp. 277-284, 2009.

[67] A. Gronlund, N. Lim, and H. Larsson, "Effective Use of Assistive Technologies for Inclusive Education in Developing Countries: Issues and Challeges from Two Case Studies," International Journal of Education and Development Using Information and Communication Technology, vol. 6, no. 4, pp. 5-26, 2010.

[68] A. De Boer, S. J. Pijil, and A. Minnaert, "Reguler Primary School Teachers' Attitudes towards Inclusive Education: A Review of Literature,” International Journal of Inclusive Education, vol. 15, pp. 331-353, 2011.

[69] K. M. Farlane and L. M. Woolfson, "Teacher Attitudes and Behaviour toward The Inclusion of Children with Social, Emotional and Behavioural Diificulties in Mainstream Schools: An Application of The Theory of Planned Behaviour," Teaching and Teacher Education, vol. 29, pp. 46-52, 2013.

[70] E. Avramidis and B. Norwich, "Teachers' Attitudes towards Integration/inclusion: A Review of The Literature," European Journal of Special Needs Education, vol. 17, no. 2, pp. 129-147, 2002.

[71] T. Booth and M. Ainscow, Index for Inclusion: Developing Learning and Participation in Schools, 3nd Edition. UK: Centre for Studies on Inclusive Education, 2011.

[72] A. Salim, Gunarhadi, and M. F. Hidayatullah, "Measuring 
Belief-based Perception towards Children with Special Needs in Inclusive Education," Universal Journal of Educational Research, vol. 8, no. 3D, pp. 19-25, 2020.

[73] L. R. Baguisa and K. Ang-Manaig, "Knowledge, Skills and Attitudes of Teachers on Inclusive Education and Academic Performance of Children with Special Needs," PEOPLE: International Journal of Social Sciences, vol. 4, no. 3, pp. 1409-1425, 2019.

[74] N. S. Dadgaran and A. Khalkhali, “The Effect of Quantum Learning Method on Students Course Learning,” Iranian Journal of Medical Education, vol. 8, no. 4, pp. 29-36, 2016.

[75] Ö. Afacan and İ. Gürel, “The Effect of Quantum Learning Model on Science Teacher Candidates' Self-efficacy and Communication Skills,” Journal of Education and Training
Studies, vol. 7, no. 4, pp. 86-95, 2019.

[76] O. Karamustafaoğlu, "“Are Mass and Weight the Same?' Activity Developed Based on Quantum Learning Model and Teachers' Opinions,” International Journal on Lifelong Education and Leadership, vol. 4, no. 1, pp. 36-40, 2018.

[77] U. M. Abba and A. M. Rashid, “Teachers’ Competency Requirement for Implementation of Inclusive Education in Nigeria,” Universal Journal of Educational Research, vol. 8, no. 3C, pp. 60-69, 2020.

[78] S. D’Alessio, "Italy and Europe with Respect to Special Education Needs," in SIPES Seminar.

[79] D. Anastasiou and J. M. Kauffman, “A Social Constructionist Approach to Disability: Implications for Special Education,” Exceptional Children, vol. 77, pp. 367384, 2011. 